\title{
Development of E-Module Momentum and Impulse Integrated the Pancasila Values Practice
}

\author{
Nur Arviyanto Himawan ${ }^{1, *}$ Ariswan $^{1}$ \\ ${ }^{1}$ Physics Education, Universitas Negeri Yogyakarta, Indonesia \\ *Corresponding author. Email: arvians21@gmail.com
}

\begin{abstract}
This study aims to determine the feasibility and response of students to the e-module momentum and impulse integrated the Pancasila values practice developed. This type of research is Research and Development used the 4-D model. The subjects of this study were 2 expert validators, 2 practitioners, 3 peer reviewers, and 26 eleventh-grade students of MAN (State Islamic Senior High School) 1 Yogyakarta. The sampling technique used is cluster random sampling. Data collection in this study used a validation sheet and questionnaire. Data collected were analyzed using descriptive analysis. Expert validation, practitioners, and peer reviewers are used to determine the feasibility of the material and media. The results of the validation analysis show the "Very Good" category with an average score of 3.86. Student responses are used to determine the readability of the e-module. The results of the student response analysis showed the "Good" category, with an average score of 3.21. Therefore, the e-module momentum and impulse integrated the Pancasila values practice are feasible for use to strengthen national character and national identity through physics learning
\end{abstract}

Keywords: e-module, momentum and impulse, integrated, Pancasila

\section{INTRODUCTION}

Globalization and the new era of the industrial revolution are increasingly reinforcing the impact of disruption. Changes in the order of life requires humans to minimize their negative effects. The lives of Indonesian people have felt the effects of globalization [1]. Globalization is the 'entrance' of foreign values that can result in moral degradation and the identity of a nation. Many countries are trying to eliminate the adverse effects of globalization through the localization movement [2]. For the Indonesian people, one such movement is to strengthen Pancasila. Pancasila, which is believed to be a national identity, is the last stronghold to prevent this negative impact [3].

Pancasila is the five principles of the Indonesian state's philosophical foundation [4]. The five principles have practical values and can be practice in life. Pancasila can be used to strengthen character, so that an ideal society is formed [5]. The character of Indonesian society, especially students, has experienced degradation due to the influence of globalization and technological development. Therefore, instilling the value of Pancasila is needed to improve student character. Philosophically, Pancasila is a strong basis for creating Indonesia's national education system [6]. The role of formal education institutions, such as high school, is very important to strengthen the value of Pancasila [7]. But Pancasila has not been an inspiration in curriculum development and learning [8]. That resulted in the practice of Pancasila values not well developed in the world of education. Teachers' creativity is needed in designing Pancasila learning to help students understand and interpret the meaning of Pancasila values correctly [9]. Therefore, the introduction of Pancasila values needs to be packaged as attractive as possible. The practice of Pancasila values can be integrated into various subjects in the school [10]. This provides an opportunity to integrate physics learning material with Pancasila values. The integration of physics learning material and Pancasila values can be presented in the description of the learning material and questions [11]. Pancasila values and physics learning material can be packaged in daily life stories [12]. The concepts of physics can be explored more deeply to obtain life wisdom in accordance with the values of 
Pancasila. The concept of physics was born from interconnected natural phenomena. Physicists have studied the phenomenon until they realize the order of the universe. The order of the universe studied in physics has provided life lessons for scientists. Therefore, learning physics at school should not stop with memorization and calculation. But it must also arrive at the meanings of life contained therein.

One of the physics learning material that is close to everyday life is momentum and impulses. There are many applications of momentum and impulses in life, such as the use of helmets, shooting with rifle, etc. Presentation of learning material by daily experience and knowledge will make it easier for students to better understand the learning material. It also provides an opportunity to be able to integrate the practice of Pancasila values in the learning material of momentum and impulses. For example, the value of "Proud as the Indonesian nation by glorifying the potential and results of his work" can be packaged in a story about a contingent of the Indonesian Army who won an international shooting competition using rifle made by PT Pindad (Indonesian state defense company). This shows that Pancasila is dynamic and can adjust the development of the times, science, and technology [6].

The learning material of momentum and impulse that is integrated with the practice of Pancasila values needs to be presented attractively by utilizing technology. Technology in the industrial revolution era is like a 'double-edged sword' that have positive and negative impacts. The use of technology in presenting learning resources is an effort to reduce negative impacts and become an example of how to use technology that is good and right. The use of technology must be in accordance with a student-centered approach in order to get a good learning experience [13]. One source of student-centered and technology-based learning resources is the electronic module (e-module). E-modules are independent learning resources that are practical, interactive, and flexible, so they can be used anytime and anywhere [14], [15]. E-modules are the solution to the era of disruption that is almost unfamiliar with distance and time in the learning process. The use of e-modules is more effective than the printed version [16]. This is because e-modules are equipped with images, videos, and animations, so that it helps students to understand the learning material [17]. Based on the description above, it is necessary to develop an emodule of momentum and impulse integrated the Pancasila values practice as a positive form of technology use, minimize the negative impact of globalization, and strengthen the nation's identity in the world of education.

\section{RESEARCH METHOD}

\subsection{Type of Research}

This research is research and development. The development procedure uses a 4-D model. This model consists of four stages, namely define, design, develop, and disseminate [18].

\subsubsection{Define Stage}

Activities carried out at this stage, namely: initial analysis, student analysis, task analysis, concept analysis, and analysis of learning objectives. The purpose of these activities is to obtain information, problems and needs so that it can be used as a guide in developing products.

\subsubsection{Design Stage}

Activities carried out at this stage, namely: preparation of tests, media selection, format selection, and initial product design. The results of the analysis of the define stage are used as a reference in making the initial design of the product.

\subsubsection{Develop Stage}

The activities carried out at this stage are product validation and product trials. The initial product design that has been created is then validated by media experts, material experts, peer reviewers, and practitioners. The results of the validation are assessment and suggestions for product improvement. Material experts and media experts were selected from Universitas Negeri Yogyakarta lecturers and UIN Sunan Kalijaga Yogyakarta lecturers. The peer reviewer are 3 masters student at Universitas Negeri Yogyakarta. While practitioners are physics subject teachers at MAN 1 Yogyakarta and MAN 4 Bantul. After being revised based on the results of the validation, the e-module momentum and impulse integrated the Pancasila values practice were trialed. The test was conducted on 26 eleventh-grade science students of MAN 1 Yogyakarta. The sampling technique used is cluster random sampling. This trial aims to obtain students' responses to the developed e-modules. The students' responses are used to revise the product, to produce the final product

\subsubsection{Disseminate Stage}

The activity carried out at this stage is to publish research results at an international conference.

\subsection{Research Instrument}

The assessment instruments used were validation sheets and student response questionnaires. Validation 
sheets are used to obtain product valuation data. Students' response questionnaire is used to obtain student responses to the product being developed.

\subsection{Analysis of Data}

The data analysis technique used in this study is a descriptive analysis. The analysis is done by calculating the results of validation and student responses. Scores from the results of validation and student responses were analyzed using Equations (1):

$\bar{X}=\frac{\text { total score }}{\text { number of evaluators }}$

The average score is used to determine the category for each aspect. Each aspect has a maximum score of 4 and a minimum score of 1 . The average score of each aspect is interpreted based on the category table. The category also shows the quality of the product being developed. Table 1 shows five assessment categories [19].

Table 1. Five assessment categories

\begin{tabular}{|l|l|}
\hline \multicolumn{1}{|c|}{ Range of Scores } & \multicolumn{1}{c|}{ Category } \\
\hline $\bar{X} \geq X_{\mathrm{i}}+1,8$ SBi & Very Good \\
\hline$X_{\mathrm{i}}+0,6$ SBi $<\bar{X} \leq X_{\mathrm{i}}+1,8$ SBi & Good \\
\hline$X_{\mathrm{i}}-0,6$ SBi $<\bar{X} \leq X_{\mathrm{i}}+0,6 \mathrm{SBi}$ & Enough \\
\hline$X_{\mathrm{i}}-1,8$ SBi $<\bar{X} \leq X_{\mathrm{i}}-0,6$ SBi & Not Good \\
\hline $\bar{X} \leq X_{\mathrm{i}}-1,8 S B i$ & Very Not Good \\
\hline
\end{tabular}

Information

$\bar{X}=$ Average score per aspect

$x_{i}=$ Average ideal score $=\frac{1}{2}$ (maximum score + minimum score)

$S B i=$ Ideal standard deviation $=\frac{1}{6}$ maximum score minimum score)

\section{RESULT AND DISCUSSION}

\subsection{Define Stage}

Observation results indicate the teacher can master the class well, but learning is teacher-centered. Learning resources and learning media used are still less varied, even though already utilizing LCD projectors. Even though it is a scientific learning method, students are still dependent on the teacher. Students look less interested in learning physics, even though the teacher has given stimulus with questions. Students have difficulty answering these questions because they have not been able to understand the concepts that have been explained by the teacher. Students also tend to wait for the teacher's answer. Students also exhibit bad behavior such as not paying attention to the teacher's explanation and disturbing the concentration of other students. This shows the low character of students.

The results of this observation are the reason for the need to develop alternative learning resources emodules integrated the Pancasila values practice. The results of other analyzes show that one of the physics learning materials that can be integrated with the practice of Pancasila values is momentum and impulse. While the results of the analysis of learning objectives in the form of core competencies, basic competencies, and learning objectives adjust the 2013 Revised Curriculum that applies in schools.

\subsection{Design Stage}

The design phase produces a storyboard, flowchart, and initial product design. Storyboards and flowchart are used as guidelines for designing e-modules. The media used to design e-modules is Articulate Storyline 3. The result of the initial design is an HTML file. The HTML file is then converted to an android application using the Website 2 APK Builder Pro program. This emodule can be operated using an Android smartphone. The initial design of the e-module integrated the Pancasila values practice has components: 1) Cover, 2) Table of contents, 3) Preface, 4) Usage Guide, 5) List of Practicing Pancasila Values, 6) Competencies and Learning Objectives, 7 ) Concept Map 8) Learning Material and Summary of Learning Material, 9) Practice questions, 10) Formative tests, 11) Glossary, 12) Bibliography, 13) Answer Key, 14) Feedback and follow-up, and 15) Developer Profile.

Integration between momentum and impulse with the practice of Pancasila values is presented in the description of the learning material and problems. The practice of Pancasila values that are integrated, namely: 1) Belief and piety to God Almighty in accordance with each other's religions and beliefs in a civilized manner, 2) Developing intercommunication and cooperation between adherents of different religions and beliefs so as to foster harmony life, 3) Developing joint ventures with a spirit of help, 4) The Indonesian nation feels itself as part of all humanity, because it developed an attitude of respect and cooperation with other nations, 5) Promoting the spirit of mutual cooperation and intercultural association for the sake of national unity and unity in diversity, 6) Proud as an Indonesian nation by glorifying the potential and results of his work, 7) In good faith and a sense of responsibility accepting and carrying out the results of deliberations, 8) Respecting differences of opinion by not forcing the will to others, 9) Likes to work hard and is innovative and appreciates the work of others, 10) Together fight for economic independence and equitable prosperity, and others. 


\subsection{Develop Stage}

The results of the develop stage are the final product of the e-module of momentum and impulse integrated the Pancasila values practice. Figure 1 shows the emodule contents list.

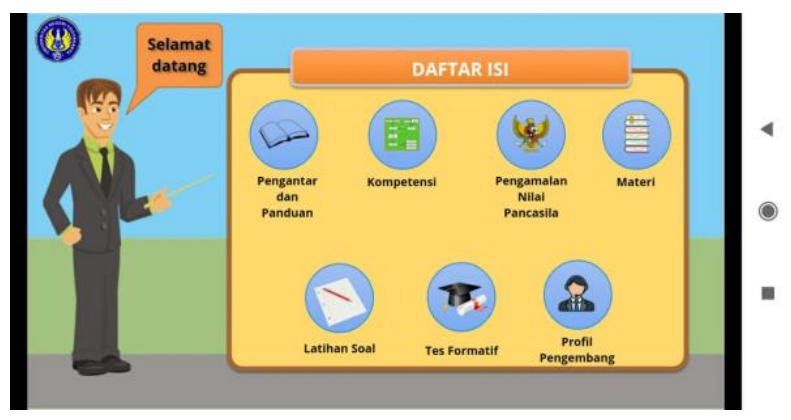

Figure 1 E-module table of content view

One example of the integration of momentum and impulse with the practice of Pancasila values in the emodule is shown in figure 2 . The concept of momentum teaches about the importance of determination or enthusiasm in working hard. Momentum is a measure of the difficulty to stop objects. We can learn from this concept of momentum that if we have the determination or enthusiasm to work hard, then we will also be difficult to stop by obstacles that stand in the way. This can be integrated with the practice value of the 5th principle of Pancasila, namely "Like working hard".

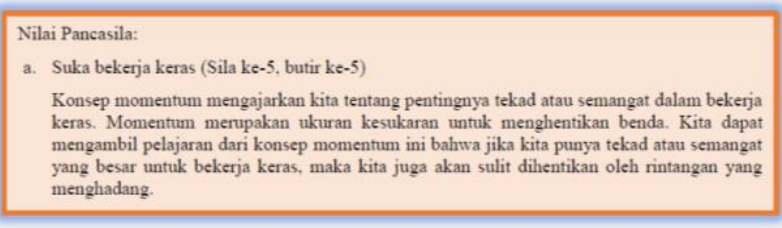

Figure 2 Integration of momentum and impulse with the practice of Pancasila values in the e-module

Another example of integration in the concept of impulse. Impulse is a change in momentum caused by external forces at work. The concept of impulse teaches that determination or passion can change. Indonesia is known as a nation that has diverse ethnicities with a high spirit of mutual cooperation (assumed as momentum). However, the spirit of mutual cooperation can fade due to outside influences (assumed as external forces), such as hoax news, provocation, racism, and others. Therefore, the Indonesian people need to be careful and need to increase unity so that the spirit of mutual cooperation does not fade. This is in accordance with one of the values of the implementation of Pancasila, namely "Promoting the spirit of mutual cooperation and intercultural association for the sake of national unity and unity in diversity".
Presentation of the law material of conservation of momentum learning material is packed with life stories that are in accordance with the values of Pancasila: "Proud as an Indonesian nation by glorifying the potential and results of his work". The story is about the contingent of the Indonesian Army who won the international level shooting competition using a rifle made by PT Pindad (Indonesian state defense company). The event of the army firing with a rifle is one of the events related to the law of conservation of momentum. The rifles the army uses are domestic products. The success of the contingent is proof that domestic products are no less competitive with foreign products. Therefore, the Indonesian people must be proud of their work.

Integration is also presented in the questions in the e-module, as shown in Figure 3. The problem is related to collision learning material. There is someone who is playing ball, then the ball hits the neighbour's pot to make it break. Then the man meets the pot owner and deliberates to solve the problem. This is the practice values of the 4th principle of Pancasila, namely "Prioritizing deliberation in making decisions concerning life together, guided by wisdom and common sense by a noble conscience".

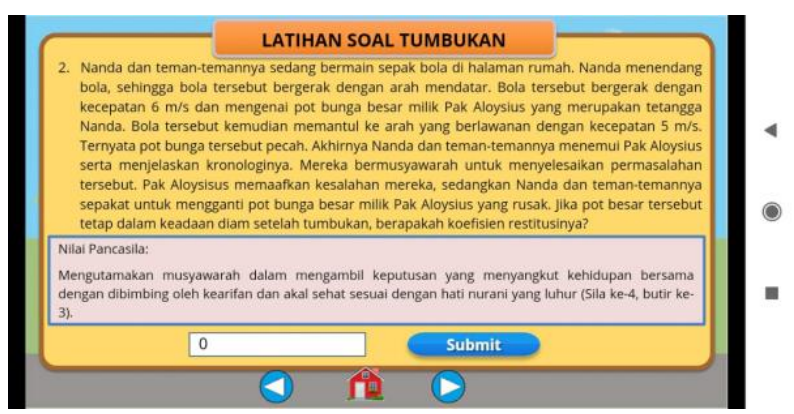

Figure 3 Question about collision learning material integrated the practice of Pancasila values

\subsubsection{Validation of the e-modules of momentum and impulse integrated the Pancasila values} practice by media experts, material experts, peer reviews, and practitioners

Validation includes the assessment of material and media. The material assessment consists of three aspects, namely: 1) Content of the material, 2) Presentation of the material, and 3) Language and pictures. Whereas media evaluation consists of:1) Display, 2) Audio, and 3) Usage. Each aspect has several sub-aspects. Scores from each sub-aspect are then analyzed to produce scores per aspect, as shown in table 2 . 
Table 2. Result of e-module validation

\begin{tabular}{|l|r|l|}
\hline Aspect & Score & Category \\
\hline Content material & 3,86 & Very Good \\
\hline Presentation of material & 3,93 & Very Good \\
\hline Language and images & 3,96 & Very Good \\
\hline Display & 3,86 & Very Good \\
\hline Audio & 3,78 & Very Good \\
\hline Usage & 3,77 & Very Good \\
\hline Average all aspect & 3,86 & Very Good \\
\hline
\end{tabular}

The results of the validation showed that all aspects of the assessment were in very good categories. Improvements made based on suggestions, include: 1) giving more interesting colors, 2) adding videos, 3) improving vector-related writing procedures, 4) sharpening the relationship between Pancasila values and physics learning material. Based on the results of the validation and the results of previous studies [20], [21], the e-module of momentum and impulse integrated the Pancasila values practice are declared suitable for use in learning.

\subsubsection{Student responses to the e-modules of momentum and impulse integrated the Pancasila values practice.}

The revised e-module results will then be tested on students. This aims to get student responses regarding the readability of the e-module being developed. Student responses consist of 6 aspects of assessment, namely: 1) The contents of the material, 2) Language and pictures, 3) Presentation of the material, 4) Display, 5) Audio, and 6) Usage. The results of student responses are shown in table 3 .

Table 3. Result of student response to e-module

\begin{tabular}{|l|r|c|}
\hline Aspect & Score & Category \\
\hline Content material & 3,26 & Good \\
\hline Presentation of material & 3.20 & Good \\
\hline Language and images & 3,25 & Good \\
\hline Display & 3,23 & Good \\
\hline Audio & 3,13 & Good \\
\hline Usage & 3,18 & Good \\
\hline Average all aspect & 3,21 & Good \\
\hline
\end{tabular}

The results of the students' responses showed all aspects of the assessment obtained a good category. The audio aspect and the usage aspect get the lowest score when compared to other aspects. This is caused when the test, the classroom atmosphere is less conducive so that the audio is less clearly heard. In addition, the process of installation on some student smartphones also encountered problems due to limited smartphone storage space. Therefore it is necessary to delete several other applications so that e-modules can be installed. This affects the acquisition of response aspects of the use of the lower aspects of other aspects. Nonetheless, the categories of student response results and the results of previous studies [20], [21], the e-module of momentum and impulse integrated the Pancasila values practice obtain positive responses so that students can be used as independent learning resources.

\subsection{Disseminate stage}

The activity carried out at this stage is to publish the results of research on 7th ICRIEMS 2020.

\section{CONCLUSION}

Based on the validation results of experts, practitioners, and peer reviewers showed the category of "very good" in every aspect of the e-module assessment. While the results of student responses show the category of "good" in every aspect of the e-module assessment. This shows that the e-module momentum and impulse integrated the Pancasila values practice are feasible for use to strengthen national character and national identity through physics learning.

\section{ACKNOWLEDGMENTS}

The authors would like to thanks DRPM Kemenristek for funding research through the 2020 master thesis research grant with contract number T/9.45/UN34.21/PT.01.03/2020

\section{REFERENCES}

[1] A. Latief, M. Nadir, T. Pangalila, A. L. Lonto, T. Suyanto, and M. Warsono, "Revitalizing the Value of Pancasila in the Development of the Character of Indonesian Citizens," in Proceedings of the 1st International Conference on Social Sciences (ICSS 2018), 2018, vol. 226, no. ICSS, pp. 923-926. http://doi.org/10.2991/icss-18.2018.191

[2] J. Zhang, "Educational Diversity and Ethnic Cultural Heritage in the Process of Globalization," Int. J. Anthropol. Ethnol., vol. 3, no. 1, pp. 1-10, 2019. https://doi.org/10.1186/s41257-019-0022-X

[3] D. Rosana, D. Setyawarno, and W. Setyaningsih, "Development Model of Students' Innert-Depend Strategies to Face Disruption Era Through Best Practice Film of Android Based Learning of Pancasila Character Value," J. Phys. Conf. Ser., 
vol. 1233, no. 2019. https://doi.org/10.1088/1742-6596/1233/1/012098

[4] Y. Latif, "The Religiosity, Nationality, and Sociality of Pancasila: Toward Pancasila through Soekarno's Way," Stud. Islam., vol. 25, no. 2, pp. 207-245,

2018. http://doi.org/10.15408/sdi.v25i2.7502

[5] A. D. Indra and D. Budimansyah, "Implementation of Pancasila Values in Improving Nationalism for Young Generation," Adv. Soc. Sci. Educ. Humanit. Res., vol. 418, no. ACEC 2019, pp. 73-76, 2019. https://doi.org/10.2991/assehr.k.200320.014

[6] A. Abdulkarim, K. Komalasari, D. Saripudin, N. Ratmaningsih, and D. N. Anggraini, "Development of a Unity in Diversity-based Pancasila Education Text Book for Indonesian Universities," Int. J. Instr., vol. 13, no. 1, pp. 371386,

2020. https://doi.org/10.29333/iji.2020.13125a

[7] F. M. P. Keraf and F. L. Kollo, "Preventing Radicalism Through The Values of Pancasila and Instilling the Value of Character in Young Citizens," Int. J. Educ. Vocat. Stud., vol. 1, no. 4, pp. 339-344, 2019. https://doi.org/10.29103/ijevs.v1i4.1470

[8] S. Sutopo, A. Nuryanto, S. Sugiyono, and P. Paryanto, "Pancasila Ethics and Culture-based Education Model for Vocational High School," J. Phys. Conf. Ser., vol. 1446, no. 1, 2020. https://doi.org/10.1088/1742$\underline{6596 / 1446 / 1 / 012055}$

[9] A. Noor and B. Bulkan, "The Meaningful Learning Of The 1st And 2nd Values Of Pancasila To Improve The Character For Indonesian Students," vol. 330, no. ICERI 2018, pp. 10-12, 2019. https://doi.org/10.2991/iceri-18.2019.3

[10] N. Mariana, J. Julaika, H. P. Paksi, and I. Rahmawati, "Exploring the Unity Value of Pancasila to Transform Mathematics Contexts in Primary School," in Advances in Social Science, Education and Humanities Research, 2018, vol. 212, no. ICEI 2018, pp. 528-533. https://doi.org/10.2991/icei-18.2018.114

[11] A. M. Sari, I. Wilujeng, and A. Satriana, "The Development of Optical Devices Learning Book Integrated with Pancasila Practice Values," J. Phys. Conf. Ser., vol. 1440, no. 1, 2020. https://doi.org/10.1088/1742-6596/1440/1/012036

[12] N. A. Himawan and I. Wilujeng, "Improving Students' Problem-Solving Skills through Quick on the Draw Model Assisted by the Optical Learning Book Integrated the Pancasila," J. Phys. Conf. Ser., vol. 1440, no. 1, 2020. https://doi.org/10.1088/1742-6596/1440/1/012031

[13] A. Oke and F. A. P. Fernandes, "Innovations in
Teaching and Learning: Exploring the Perceptions of the Education Sector on the 4th Industrial Revolution (4IR)," J. Open Innov. Technol. Mark. Complex., vol. 6, no. 2, 2020. https://doi.org/10.3390/joitmc6020031

[14] F. A. Perdana, S. Sarwanto, S. Sukarmin, and I. Sujadi, "Development of E-module Combining Science Process Skills and Dynamics Motion Material to Increasing Critical Thinking Skills and Improve Student Learning Motivation Senior High School," Int. J. Sci. Appl. Sci. Conf. Ser., vol. 1, no. $1, \quad$ p. 2017. https://doi.org/10.20961/ijsascs.v1i1.5112

[15] D. Darmajie, A. Astalin, D. A. Kurniawan, H. Parasdila, I. Irdianti, S. Subiyanto, K. Kuswanto, M. Ikhlas, "E-Module based Problem Solving in Basic Physics Practicum for Science Process Skills," Int. J. Online Biomed. Eng., vol. 15, no. 15, pp. 4-17, 2019 . https://doi.org/10.3991/ijoe.v15i15.10942

[16] Astalini, Darmaji, W. Kurniawan, K. Anwar, and D. A. Kurniawan, "Effectiveness of Using EModule and E-Assessment," Int. J. Interact. Mob. Technol., vol. 13, no. 9, pp. 21-39, 2019. https://doi.org/10.3991/ijim.v13i09.11016

[17] N. Fadieny and A. Fauzi, "The Analysis of Instructional Media in Development of Lightning E-module for Physics Learning in Senior High School," J. Phys. Conf. Ser., vol. 1185, no. 1, 2019. $\underline{6596 / 1185 / 1 / 012078}$

[18] S. Thiagarajan, D. S. Semmel, and M. . Semmel, Instructional Development for Training Teachers of Expectional Children. Minnesota: Leadership Training Institute/Special Education, University of Minnesota, 1974.

[19] E. P. Widoyoko, Evaluasi Program Pembelajaran: Panduan Praktis bagi Pendidik dan Calon Pendidik. Yogyakarta: Pustaka Pelajar, 2009.

[20] W. Suwatra, A. Suyatna, and U. Rosidin, "Development of Interactive E-Module for Global Warming to Grow of Critical Thinking Skills," Int. J. Adv. Eng. Manag. Sci., vol. 4, no. 7, pp. 543549, 2018. http://doi.org/10.22161/ijaems.4.7.7

[21] M. A. Fatkhurrohman and W. J. Kusuma, "The Developing of Modul on Science School Material With Pancasila Character," J. Pena Sains, vol. 6, no. $1, \quad$ p. 10,2019 . https://doi.org/10.21107/jps.v6i1.4533 